\title{
Developing a Method of Understanding Tafsir Nur Al-Ihsan Using Intertextual Reading: A Study using the Excerpt Method
}

Mohd Sholeh Sheh Yusuff, Yusuf Haji-Othman, Tengku Zawani Tengku Zawawi

To Link this Article: http://dx.doi.org/10.6007/IJARBSS/v11-i6/10102 DOI:10.6007/IJARBSS/v11-i6/10102

Received: 06 April 2021, Revised: 12 May 2021, Accepted: 28 May 2021

Published Online: 08 June 2021

In-Text Citation: (Yusuff et al., 2021)

To Cite this Article: Yusuff, M. S. S., Haji-Othman, Y., \& Zawawi, T. Z. T. (2021). Developing a Method of Understanding Tafsir Nur Al-Ihsan Using Intertextual Reading: A Study using the Excerpt Method. International Journal of Academic Research in Business and Social Sciences, 11(6), 127-134.

Copyright: (C) 2021 The Author(s)

Published by Human Resource Management Academic Research Society (www.hrmars.com) This article is published under the Creative Commons Attribution (CC BY 4.0) license. Anyone may reproduce, distribute, translate and create derivative works of this article (for both commercial and non-commercial purposes), subject to full attribution to the original publication and authors. The full terms of this license may be seen at: http://creativecommons.org/licences/by/4.0/legalcode

Vol. 11, No. 6, 2021, Pg. 127 - 134

Full Terms \& Conditions of access and use can be found at http://hrmars.com/index.php/pages/detail/publication-ethics 


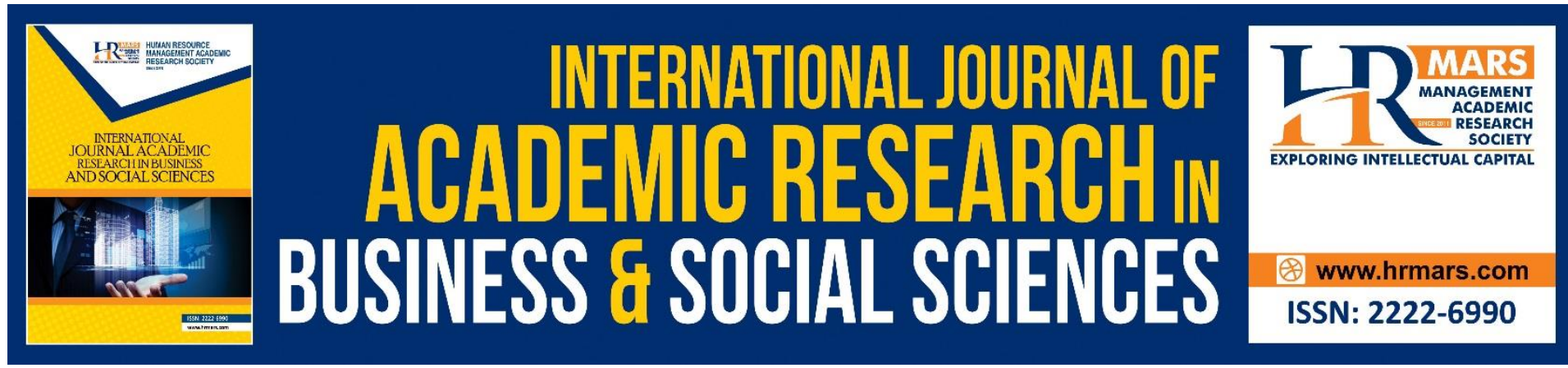

\title{
Developing a Method of Understanding Tafsir Nur Al-Ihsan Using Intertextual Reading: A Study using the Excerpt Method
}

\author{
Mohd Sholeh Sheh Yusuff, Yusuf Haji-Othman, Tengku Zawani \\ Tengku Zawawi \\ Sultan Abdul Halim Mu'adzam Shah International Islamic University (UniSHAMS), Malaysia
}

\begin{abstract}
Tafsir Nur al-Ihsan is the second interpretation after Tarjuman al-Mustafid written in the Malay language in the 19th century AD by Sheikh Muhammad Sa'id ibn Umar. The main objective of this study is to identify the influence of the external source in the text of Tafsir Nur al-Ihsan. This study employs intertextual reading based on dialogism in the process of analyzing Tafsir Nur al-Ihsan based on excerpt method. The research design used is documentation and field work using the subjective approach that employs descriptive and qualitative data. The study reveals that there are 11 works which have influenced the essence of Tafsir Nur al-Ihsan which are Tafsir al-Jalalyn, Tafsir al-Jamal, Tafsir al-Baydawi, Tafsir alKhazin, Tafsir al-Baghawi, Tafsir al-Tabari, Tafsir al-Qurtubi, Tafsir al-Razi, Tafsir al-Nasafi, Tafsir Ibn Kathir, and Tafsir al-Tha'labi. The finding analysis also reveals that Tafsir Nur al-Ihsan is mostly influenced by Tafsir al-Jamal.
\end{abstract}

Keywords: Dialogism, Tafsir Nur al-Ihsan, Intertextual Reading, Excerpt Method.

\section{Introduction}

The writings of Islamic works and translations into the Malay language have grown tremendously since the coming of Islam to Nusantara regions (Malaysia, Thailand, Brunei and Indonesia), which have covered various fields and branches of knowledge such as fiqh, aqidah, tafsir, hadith, and Sufism, among others. The writings and translations by previous Islamic scholars have remained as important sources of reference and are still used by contemporary scholars for academic purposes. It shows the success of previous Islamic scholars who produced writings which have not only attracted the interest of the public but also have benefited them. One of the Islamic scholars was Haji Muhammad Sa'id bin Omar Qadi Jitra alQadhi who produced a book in the field of Tafsir in the Malay language entitled Tafsir Nur alIhsan.

Tafsir Nur al-Ihsan has been a reference in understanding Qur'anic verses not only by the public but also contemporary scholars who have used it as a teaching material. This invaluable piece of work has given a contribution to the knowledge of the public at large so much so that scholars are attracted to study and examine this work from various aspects such as history, language, the influence, and stature of the author. 
Tafsir Nur al-Ihsan is also one of the books on Tafsir al-Qur'an, which is still being used as a teaching material and reference today especially at Pondok institutions, mosques, and musollas. Pondok institutions such as Pondok Tuan Guru Haji Bakar at Kedah, Malaysia and Pondok Tuan Guru Haji Salleh Musa at Kedah, Malaysia have been using the book as the teaching material for their weekly teaching. However, there have been criticisms on the content of Tafsir Nur al-Ihsan by certain sections of the public. Some of them opined that this book has its shortcomings because in the writing of this book, the author does not mention any citation and uses many unjustified opinions in his tafsir (Zaim, 2010), so much so that the public should be careful when reading Tafsir Nur al-Ihsan (Taib, 2003).

Since Tafsir Nur al-Ihsan has been used as a teaching material in the Tafsir al-Qur'an and a reference by the public at large in understanding verses of al-Qur'an, then efforts to refine this piece of work should be made. This study is one of the efforts which attempts to refine sources of reference and interconnections between the original text and other Tafsir texts using intertextual reading. This will answer the aforementioned problem statement. The objective of this study is to examine Tafsir Nur al-Ihsan in order to examine whether there exist the influence of other texts on the text of Tafsir Nur al-Ihsan using intertextual reading. This study focuses on the application of excerpt method on the text of Tafsir Nur al-Ihsan as an early effort towards the refinement of the text which contributes to improving the invaluable work. Since the author of Tafsir Nur al-Ihsan mentioned that he referred to works in the field of Tafsir while in the process of writing (Sa'id, 1970), this study focuses only on Tafsir works. From the perspective of methodology, this study employs library research and field study using subjective approach to examine data descriptively and qualitatively.

\section{Intertextual Reading Method}

The intertextual reading method was originally known as dialogic which was introduced by Bakhtin in the year 1926 because there was voluminous Russian art literature which was difficult to comprehend at that time. As a consequence, this theory was introduced by Bakhtin in order to facilitate readers to understand the difficult literature. This theory considered that all literature which was written was based on dialogues between one text and another. In other words, this theory states that any text is influenced by other texts. This is supported by Harari (1979), who mentioned that "every text, being itself the intertext of another text, belong to the intertextual, which must not be confused with a text's origins".

The basis of this dialogic theory is used to understand Dostoevsky's literature such as The Gambler, The Idiot and The Brother's Karamazov which were considered as difficult to be understood by the public using theories of literature such as formalism which were dominant during that time (Dostoyevsky, 1967). The Russian formalism approach which was on the rise during that time did not help the public to understand the approach of Dostoevsky's literature. Bakhtin's dialogism emphasized external aspect which influenced reading or how an author approached art literature and in turn would flow naturally into his own literature writing. However, Bakhtin did not deny the importance of internal elements such as theme, thought, plot, characters and other elements.

In the theory of dialogism, an author would have a dialogue with the text itself, himself and readers. This would create dialogues between a text and another text and as a consequence, it would trigger changes, conflicts, and expansion in the literature which was being written by the author in terms of theme and problems, plot or characters and characterization. Therefore, the relation between external and internal structures in a literature is important 
in this approach. According to Schmitz (2007), sentences used by someone in speech or writing interconnects among them and if there is no dependency among them, then any sentence or speech becomes gloomy and inexpendable. Schmitz (2007) mentioned;

"Language always works within certain situations, and utterances produce their significance within this context. The linguistic material alone is not enough to determine whether a word or a sound is enthusiastic, gloomy, ironical, threatening, or deferential; rather, this depends on a number of factors such as intonation, volume, the interlocutor, and prior utterances in the dialogue" (Schmitz, 2007).

This theory was later discussed by Kristeva (1980) in her PhD thesis entitled La revolution du Langage Poetique in 1970. However, Kristeva did not name this theory as dialogic, instead, she termed it as intertextuality. Hawthorn (2000) mentioned that every text which was written was influenced by other texts and this influence was discussed in intertextual theory. Therefore, readers should not be confused with the original text which is the hipogram of a given text. Hawthorn (2000) stated that "Kristeva defines the text as a permutation of texts, an intertext in the space of a given text...".

The development of this theory not only have taken place in Europe but also in the whole worldwide. In Southeast Asia, it has been discussed as one of modern literary theory in which one scholar in the field of literature named Sardjono (1986) has developed this theory. He has not only stood on the principles of Kristeva but has also introduced another principle termed as excerpts. This principle applies when a text incarnated in another text in an abstract form. Subsequently, there was the birth of new names in Indonesia such as Teeuw and Umar. Meanwhile, in Malaysia and Singapore, it became known after Abdul Rahman Napiah discussed in several books, particularly in his PhD thesis entitled "Tuah Jebat in Malay Drama: A Study of Intertextuality", in 1989. In this thesis, he not only discussed this theory at length but also applied it to the book entitled Hikayat Hang Tuah.

Upon examination of the book entitled Desire in Language: A Semiotic Approach to Literature and Art by Kristeva (1980) and Kakawin Gajah Mada by Sardjono (1986), there are 10 intertextual principles which have often appeared in literature and manifestation reflected in a person's style of writing, namely transformation, modification, expansion, demitefication, haplology, excerpt, parallel, conversion, existence and defamiliarization. Each of these principles does not have to appear separately in a certain work, which means that some of them could appear simultaneously. For example, when a particular text goes through a transformation process, it could also pass through modification process, expansion or any other intertextual principles at the same time.

\section{Application of Excerpt Method in Tafsir Nur Al-Ihsan}

This article looks at only one angle from the aspect of applying the form of intertextual method, namely the application of excerpt method. In Tafsir Nur al-Ihsan, there are five debates discussed by Sheikh Muhammad Sa'id including The Contexts and Occasions of the Revelation of the Qur'an, hadiths, the stories of isra'iliyyat, The Abrogating and Abrogated Verses in the Qur'an (Nasikh and Mansukh) and The Text about Advantages (Fadhilat). However, the discussion did not include the source of the intake. Such a thing causes the author's interpretation to be disputed by some scholars, especially on explanations that are 
apparently contrary to reason and sharia. However, the results of the research that has been done found that the discussion is sourced from the works of muktabar such as Tafsir Ibn Kathir, Tafsir al-Baydawi and Tafsir al-Qurtubi which is indeed certified in its interpretation value (al-Dhahabi, 2005).

Excerpt is one of the methods listed in the forms of intertextual methods used to identify text sources that are general and abstract. This method occurs when the author of a work translates the meaning of a text from a particular work into the text being written. This is because the author has been influenced by the reading material that is read and then translated into his own text. According to Hajar (2013), the most dominant form of intertextual methods in influencing the writing of a work is the excerpt method. This method is described as a method that will be applied in any work even if the author is not aware of it. A thesis produced is influenced by previous studies, as well as articles, newspapers, books and even novels that are inevitably influenced by existing writings.

Moreover, this method also indeed affects the original text. When an author moves a text into his text it is possible to change the order of the text and language, adding meaning or deleting a text. This method can also benefit the reader where the application of this method is able to give the reader an understanding of the true meaning of the author in his writing which may on the surface seem a little confusing. In line with the study of the work of Tafsir Nūr al-Ihsān, this method can also strengthen the reader's confidence in the interpretation made by the author after the original source referred to by the interpreter is identified, even elevating the dignity of Tafsīr Nūr al-Ihsān on par with other works of muktabar. An example of the application of this method can be seen in the writings of Sheikh Muhammad Sa'id (1970. vol. 1:68) in Tafsir Nur al-lhsan, namely: "and this verse came down when the Muslims faced hardship in the Khandak war".

While the text from Tafsir al-Khazin (1979, vol. 1: 202) which is the original work that was transformed:

نزلت في غزوة الأحزاب وهي غزوة الخندق ، وذلك أن المسلمين أصابهم من الجهد والشدة والخوف والبرد وضيق العيش الذي كانوا فيه يومئذ الذزئ

Both texts explain the reason for the decline of the 214th verse of surah al-Baqarah narrating about the difficulties faced by the Muslim army in the face of the Khandak war. After examining both texts it is found that the text of Tafsir Nur al-Ihsan is shorter than the text of Tafsir al-Khazin. Even so, both texts express the same information and meaning. Through this method, the reader can detect the relationship between the two texts in terms of the alignment of the meaning to be conveyed, even if the arrangement of the two texts does not match each other. Therefore, the application of excerpt method in conducting this research is important to identify the original source of a text in the text of Tafsir Nur al-Ihsan which is abstract. 
INTERNATIONAL JOURNAL OF ACADEMIC RESEARCH IN BUSINESS AND SOCIAL SCIENCES Vol. 11, No. 6, 2021, E-ISSN: 2222-6990 @ 2021 HRMARS

The Works Which Have Influenced The Content Of Tafsir Nur Al-Ihsan Using Excerpt Method

Table 1: The List of Works which Influence the Contents of the Tafsir Nur Al-Ihsan Using Excerpt Method

\begin{tabular}{|c|c|c|c|c|c|c|c|c|}
\hline $\begin{array}{l}\mathbf{N} \\
\mathbf{O}\end{array}$ & Works & $\begin{array}{l}\text { Contexts } \\
\text { and } \\
\text { Occasions } \\
\text { of the } \\
\text { Revelation } \\
\text { of the } \\
\text { Qur'an }\end{array}$ & Hadith & $\begin{array}{c}\text { Stories } \\
\text { of al- } \\
\text { Israiliyy } \\
\text { at }\end{array}$ & $\begin{array}{c}\text { Nasikh } \\
\text { and } \\
\text { Mansuk } \\
h\end{array}$ & $\begin{array}{c}\text { Fadhil } \\
\text { at }\end{array}$ & $\begin{array}{c}\text { Tota } \\
\text { I }\end{array}$ & $\begin{array}{c}\text { Perc } \\
\text { enta } \\
\text { ge }\end{array}$ \\
\hline 01 & Tafsir al-Jalalyn & 11 & 6 & 7 & 11 & - & 35 & 13.6 \\
\hline 02 & Tafsīr al-Jamal & 30 & 3 & 78 & 3 & 2 & 116 & 45 \\
\hline 03 & Tafsīr al-Bayḍāwī & 8 & 2 & 10 & - & 2 & 22 & 8.5 \\
\hline 04 & Tafsīr al-Khāzin & 16 & 6 & 23 & 1 & 1 & 47 & 18.2 \\
\hline 05 & Tafsīr al-Baghawī & - & 5 & 3 & - & - & 8 & 3.1 \\
\hline 06 & Tafsīr al-Tabarī & - & 2 & - & - & - & 2 & 0.7 \\
\hline 07 & Tafsīr al-Qurțubī & 4 & 7 & 2 & - & - & 13 & 5 \\
\hline 08 & Tafsīr al-Rāzī & 5 & - & - & - & - & 5 & 2 \\
\hline 09 & Tafsīr al-Nasafī & 1 & 1 & - & - & - & 2 & 0.7 \\
\hline 10 & Tafsīr Ibn Kathīr & - & 6 & - & - & - & 6 & 2.3 \\
\hline 11 & Tafsīr al-Tha'labī & - & - & 2 & - & - & 2 & 0.7 \\
\hline & Total & 75 & 38 & 125 & 15 & 5 & 258 & 100 \\
\hline
\end{tabular}

Table 1 explains the data which were analyzed based on the excerpt method. This study finds that the Tafsir Nur al-Ihsan was influenced by Tafsir al-Jalalyn 35 times (13.6\%), Tafsir alJamal 116 times (45\%), Tafsir al-Baydawi 22 times (8.5\%), Tafsir al-Khazin 47 times (18.2\%), Tafsir al-Baghawi 8 times (3.1\%), Tafsir al-Tabari 2 times (0.7\%), Tafsir al-Qurtubi 13 times (5\%), Tafsir al-Razi 5 times (2\%), Tafsir al-Nasafi 2 times (0.7\%), Tafsir Ibn Kathir 6 times (2.3\%) and Tafsir al-Tha'labi 2 times (0.7\%). Therefore, the text which has the most influence on Tafsir Nur al-Ihsan using excerpt method is Tafsir al-Jamal.

\section{Conclusion}

Based on this study, it could be concluded that intertextual approach has its own method. This method combines processing, construction, and digestion of the two aspects which are internal and external aspects of the construction of a piece of work. The internal aspect is observed when the authors set the style of interpretation (tafsir) according to their own aspirations, while the external aspect is when there exist the external works which affect the written text. Tafsir Nur al-Ihsan is a tafsir which was written by Sa'id (1970). This work has received widespread acceptance not only in Malaysia but also in Egypt and Thailand on par with other contemporary tafsir. What is interesting about this work is its brief presentation style even understandable by the laymen and is also loaded with various knowledge. His easy style meets the needs of all levels of society and is suitable for use by modern civil society such as Malaysia.

Sa'id (1970) referred to 11 venerated works which are Tafsir al-Jalalyn, Tafsir al-Jamal, Tafsir al-Baydawi, Tafsir al-Khazin, Tafsir al-Baghawi, Tafsir al-Tabari, Tafsir al-Qurtubi, Tafsir al- 
Razi, Tafsir al-Nasafi, Tafsir Ibn Kathir, and Tafsir al-Tha'labi in debating 75 contexts and occasions of the revelation of the Qur'an, 38 Hadith of the Prophet, 125 stories of alIsra'iliyyat, 15 the Abrogating and Abrogated Verses in the Qur'an (Nasikh and Mansukh) and 5 the Text about Advantages (Fadhilat), which are very interesting for the people to learn and live by. Through this study, the sources of references for all referred texts and the information which was omitted from the original text are identified. Therefore, this study provides evidence that Sa'id (1970) neither use unsupported facts nor use his own opinion in producing the literature entitled Tafsir Nur al-Ihsan.

In conclusion, this study provides evidence that the main reference of Tafsir Nur al-Ihsan is Tafsir al-Jamal based on the percentage of frequency that Sa'id (1970) referred to it more than any other works. While the Tafsir al-Jalalyn, Tafsir al-Baydawi, Tafsir al-Khazin, Tafsir alBaghawi, Tafsir al-Tabari, Tafsir al-Qurtubi, Tafsir al-Razi, Tafsir al-Nasafi, Tafsir Ibn Kathir, and Tafsir al-Tha'labi were the side works which were used by the author as references.

\section{References}

Zaydan, A. K. (1996). Al-Wajiz fi Usul al-Fiqh. Beirut. Mu'assasah al-Risalah.

Al-Latif, A. (1989). al-Barahin al-Islamiyyah fi Radd al-Shubhat al-Farisiyyah. w.p. Maktabat al Hidayah.

Razak, A. A. R. (2010). "Mengenali Tuan Haji Saaid Mufti Ulama Tersohor di Alam Melayu", Kertas kerja di Seminar Ulama Melayu, Shah Alam, 23 Mei.

Razak, A. O. (2012). "Tafsir Nur al-Ihsan: Satu Pengenalan". interview. 07 Julai.

Al-Dhahabi, M. H. (1977). 'Ilm al-Tafsir. Al-Qahirah. Dar al-Ma'arif.

Al-Hakim, M. A. A. (1417H/1997M). Al-Mustadrak (ala al-Sahihyn. Al-Qahirah. Dar alHaramayn li al-Taba'ah wa al-Nashr wa al-Tawzi'.

Al-Jamal, S. U. (2013). Tafsīr al-Jamal. Mesir. 'Isa al-Babi al-Halabi.

Al-Khazin, A. D. (1339H/1979M). Tafsir al-Khazin. Beirut. Dar al-Fikr.

Asmad. (1987). Kedah. Melaka. Associated Educational Distributor (M) Sdn. Bhd.

Dostoyevsky, F. (1975). The Idiot. David Magarshack. England: Peguin Books.

Ibn Khaldun, A. R. (2000). Muqaddimah Ibn Khaldun. Beirut. Dar Sadir.

Hawthorn, J. (2000). A Concise Glossary of Contemporary Literary Theory. London: Arnold.

Harari, J. V. (1979). Textual Strategies. New York. Cornell University Press.

Kristeva, J. (1980). Desire in Language: A Simeotik Approach to Literature and Art. Oxford. Basil Blackwell.

Sikana, M. (1999). Teori dan Pendekatan Kususasteraan 1. Bangi. Universiti Kebangsaan Malaysia.

Zaim, M. N. (2010). Kajian Takhrij Hadis Dalam Tafsīr Nūr al-Iḥsān . (Unpublished Master Dissertation). Universiti Sains Malaysia.

Taib, M. I. M. (2003). "Israiliyyat Dalam Tafsir: Kajian Terhadap Kitab Nur al-Ihsan, Karya Haji Muhammad Sa'id bin 'Umar". Unpublished Master Dissertation. Universiti Malaya.

Sa'id, M. (1391H/1970M). Tafsir Nur al-Ihsan, Fatani: Matba'ah Bin Halabi.

Itr, N. D. (1996). 'Ulum al-Qur'an al-Karim. Dimashq. Dar al-Hubl.

Sardjono, P (1986). Kakawin Gadjah Mada. Bandung: Penerbit Binacipta.

Hajar, S. C. M. (2013). Bacaan Intertekstual. interview. 18 Mac.

Schmitz, T. A. (2007). Modern Literary Theory and Ancient Texts an Introduction. Voctoria: Blackwell Publishing. 
INTERNATIONAL JOURNAL OF ACADEMIC RESEARCH IN BUSINESS AND SOCIAL SCIENCES

Vol. 11, No. 6, 2021, E-ISSN: 2222-6990 @ 2021 HRMARS

Nasyrudin, W. A. (2008). "Tafsir Tarjuman al-Mustafid: Kajian Intertekstual", Unpublished Doctor of Philosophy thesis, Universiti Malaya. 